$\square$ 寄生虫学 $\square \quad$ Full paper

\title{
A Fatal Case of Bronchopneumonia Associated with Lungworm Infection in a Bottle-nosed Dolphin, Tursiops truncatus (Cetacea: Delphinidae)
}

Hideo KUMAZAWA ${ }^{1)}$, Rishou YONA ${ }^{2)}$, Mayumi HIRAI ${ }^{2)}$, Hideo HASEGAWA ${ }^{3)}$

1) Department of Parasitology, Kochi Medical School, Nankoku, Kochi 783-8505, Japan

2) Kochi Livestock Hygiene Service Center, Tosa City, Kochi 781-1102, Japan

3) Department of Infectious Diseases, Faculty of Medicine, Oita University, Hasama, Oita 879-5593, Japan

(2004 年 8 月 23 日受領, 2006 年 1 月 25 日採択)

\author{
肺虫感染を伴う気管支肺炎によるバンドウイルカ Tursiops truncatus \\ （鯨目マイルカ科）の1 死亡例 \\ 熊沢秀雄 ${ }^{12}$, 與名理昇 ${ }^{2)}$, 平井真弓 ${ }^{2)}$, 長谷川英男 ${ }^{3)}$ \\ 1）高知大学医学部寄生虫学教室 $\bar{\top} 783-8505$ 高知県南国市岡豊町小蓮 \\ 2）高知県中央家畜保健衛生所 $\bar{T} 781-1102$ 高知県土佐市高岡町乙 3229 \\ 3）大分大学医学部感染分子病態制御講座 (生物学) ₹ 879-5593 大分県狭間町医大が丘 $1-1$
}

\begin{abstract}
A fatal case of bronchopneumonia associated with lungworms in a bottle-nosed dolphin, Tursiops truncatus, in an aquarium in Kochi, Kochi Prefecture, Japan, was studied. Numerous adult lungworms (Stenurus ovatus (Linstow, 1910) (Metastrongyloidea: Pseudaliidae)) were found in the bronchioles of the lungs. The nematodes as well as secondary bacterial infections may have been responsible for the development of pulmonary lesions.
\end{abstract}

Key words: bottle-nosed dolphin, bronchopneumonia, Stenurus ovatus

Jpn. J. Zoo Wildl. Med. 11(1) : 31-34, 2006

This report describes a case of fatal bronchopneumonia associated with lungworm infection in a bottle-nosed dolphin, Tursiops truncatus. The lungworm was identified as Stenurus ovatus (Linstow, 1910), and its detailed morphology along with a taxonomical discussion will be given elsewhere [1]. Some specimens (10 males and 10 females) collected from the present case were deposited in the National Science Museum, Tokyo, under accession number NSMT-As 3028. Others ( 3 males and 5 females) were deposited in the Natural History Museum in London under the registration number 2004.1.14.1-8.

Two female dolphins captured in the Pacific Ocean off Taiji, Wakayama Prefecture, Japan, were sent to the Katsurahama Aquarium, Kochi, Kochi Prefecture, Japan, on December 24, 2002. They were fed on thawed mackerel and raw saurel. An anomalous, permanent curvature of the lumbar vertebral column occurred accidentally to one of the dolphins on January 24,2003 . This dolphin became rapidly emaciated and died on January 28. Dissection on the next day showed pneumonia, duodenal constriction, and denaturation of muscles at the vertebral curvature.

The remaining dolphin, then alone in the pool, soon showed diminished activity with feeble respiration. Based on a bacteriological examination of expirated air collected on February 4 (see below), treatment with an oral administration of chloramphenicol was started on February 14. Although the dolphin seemed to recover temporarily, her condition worsened after February 23, after which a loss of appetite, diarrhea, and dermatitis in the skin of the tail fin were observed. Despite continued treatment with various combinations of antibiotics and other drugs, based partly on a bacteriological examination of the dermatitis, the dolphin became gradually emaciated, and died on April 9, 2003 after severe vomiting and dyspnea.

Clinical examinations were conducted by the Kochi Branch of Falco Biosystems Co., Ltd., Kochi, using blood and other samples taken at various times after the dolphin was brought to the aquarium. Blood samples showed a decline in eosinophills and increases in various data including those of red blood cells and related parameters, neutrophil counts, and some enzymes (Table 1). Those increases were especially prominent on March 29. Upon a bacteriological examination, a blood-agar culture of expirated air collected on February 4 revealed Vibrio alginolyticus and Staphylococcus epidermidis, both of which proved resistant to cephalosporin but sensitive to chloramphenicol. From the dermatitis foci sampled on March 7, $V$. alginolyticus and Morganella morganii, both sensitive to chloramphenicol, an ampicilin-sensitive Staphylococcus sp., and an unidentified fungus were isolated.

A post-mortem examination of the dolphin was performed on April 10 at the Kochi Livestock Hygiene Service Center, Tosa, 
Table 1. Hematology and serum biochemistry of a bottle-nosed dolphin Tursiops truncatus infected with Stenurus ovatus.

\begin{tabular}{|c|c|c|c|c|}
\hline Parameters $^{1)}$ & Dec. 25,02 & Mar. 20, 03 & Mar. 29, 03 & Normal Ranges ${ }^{2)}$ \\
\hline$\overline{\mathrm{RBC}\left(10^{4} / \mu 1\right)}$ & 456 & 480 & 455 & $300-400$ \\
\hline $\mathrm{Hb}(\mathrm{g} / \mathrm{dl})$ & 19.4 & 20.5 & 19.2 & $12.7-15.5$ \\
\hline $\mathrm{HCT}(\%)$ & 55.9 & 59.2 & 54.6 & $37-47$ \\
\hline $\operatorname{MCV}(\mathrm{fl})$ & 122.6 & 123.3 & 120 & $111-135$ \\
\hline MCHC (g/dl) & 34.7 & 34.6 & 35.2 & $32-36$ \\
\hline Leukocytes $/ \mu 1$ & 8,900 & 15,800 & 25,700 & $5,000-12,400$ \\
\hline Neutrophils/ $\mu 1$ & 7,832 & 14,220 & 22,873 & $2,537-6,143$ \\
\hline Lymphocytes/ $\mu 1$ & 534 & 790 & 1,542 & $523-2,423$ \\
\hline Monocytes $/ \mu 1$ & 445 & 790 & 1,028 & $81-611$ \\
\hline Eosinophils/ $\mu 1$ & 89 & 0 & 0 & $527-4,533$ \\
\hline Basophils/ $\mu 1$ & 0 & 0 & 257 & $0-33$ \\
\hline Plasma proteins $(\mathrm{g} / \mathrm{dl})$ & 7.3 & 7.9 & 7.7 & $6.0-8.8$ \\
\hline Albumin $(\mathrm{g} / \mathrm{dl})$ & 4.1 & 4.1 & 3.8 & $2.9-5.3$ \\
\hline Globulin $(\mathrm{g} / \mathrm{dl})$ & 3.2 & 3.8 & 3.9 & $1.3-5.5$ \\
\hline Glucose (mg/dl) & 154 & 115 & 118 & $62-170$ \\
\hline BUN (mg/dl) & 60.5 & 84.1 & 79.8 & $42-72$ \\
\hline $\operatorname{ALP}(\mathrm{U} / \mathrm{l})$ & 662 & 587 & 560 & $51-1,300$ \\
\hline GPT (U/1) & 67 & 184 & 738 & $9-60$ \\
\hline GOT (U/l) & 301 & 551 & 1,887 & $133-318$ \\
\hline$\gamma$-GTP (U/1) & 48 & 86 & 152 & $17-50$ \\
\hline CPK (U/1) & 321 & 135 & 355 & $100-250$ \\
\hline LDH (U/1) & 645 & 949 & 2,034 & $324-538$ \\
\hline Calcium $(\mathrm{mg} / \mathrm{dl})$ & 9.3 & 9.4 & 9.3 & $8.2-10.0$ \\
\hline Phosphorus (mg/dl) & 6.8 & 6 & 6.4 & $3.2-7.2$ \\
\hline Sodium $(\mathrm{mEq} / \mathrm{l})$ & 154 & 154 & 152 & $151-158$ \\
\hline Potassium $(\mathrm{mEq} / \mathrm{l})$ & 3.2 & 4.2 & 4 & $3.2-4.4$ \\
\hline Chloride $(\mathrm{mEq} / \mathrm{l})$ & 107 & 104 & 106 & $108-125$ \\
\hline
\end{tabular}

1) Abbreviations: ALP, alkaline phosphatase; BUN, blood urea nitrogen; CPK; creatine phosphokinase; GOT, glutamic oxalacetic transaminase; GPT, glutamic pyruvic transaminase; $\gamma$-GTP, $\gamma$ - glutamil transpeptidase; Hb, hemoglobin; HCT, hematocrit; LDH, lactate dehydrogenase; MCHC, mean corpuscular hemoglobin concentration; MCV, mean corpuscular volume; RBC, red blood cells.

2) Reference [2].

Kochi Prefecture. The lungs showed suppurative purulent pneumonia, with abscesses, $2-3 \mathrm{~cm}$ in diameter, in the distal portion of the left posterior lobe (Fig. 1). The spleen showed diffuse petechial bleeding in the capsule, and the main (second) stomach exhibited hyperemia and bleeding in the mucosa. No significant changes were observed in other organs. Two species of nematode were found: S. ovatus in the lung and Crassicauda $\mathrm{sp}$. in the connective tissue surrounding the skeletal muscle.

Organs and tissues were fixed in $10 \%$ buffered formalin, and processed for routine histopathological examination. Numerous adults of S. ovatus (Figs. 2 and 3) were present, as well as fibrin, cell debris, macrophages, neutrophils, and occasional clusters of gram-negative bacilli in the lumen of the bronchioles. The adult females had a large number of larvae in the uteri. The bronchiolar epithelium frequently showed various degrees of squamous metaplasia. Multi-focal calcification was observed in the bronchiolar mucosa. Fibrous areas in the mucosa sometimes contained small vessels, which may have indicated angiomatosis $[3,4]$. Larvae of S. ovatus were also present in the bronchiolar lumina and alveolar spaces, with prominent fibrinous exudates and macrophage infiltrations (Fig. 4). No inflammation occurred where worms were absent. Occasional macrophages contained a large number of hemosiderin granules. Thick aggregations of lymphocytes were often observed in the alveolar interstitium. The alveolar septa showed hyperemia but no hemorrhaging.

Congestion was observed in the main stomach mucosa, spleen, and adrenal gland. The liver showed congestion in and around the central veins, often accompanied by scattered necrotic foci. Neither of these organs showed an infiltration of inflammatory cells.

A single female of another nematode species, Crassicauda sp., was found in the connective tissue surrounding the skeletal muscle tissue near the tail. Sectioned preparations revealed that the worm, with numerous eggs in the uteri, was surrounded by a thick, fibrous layer, with various degrees of infiltration by lymphocytes, plasma cells, macrophages, and occasional multinucleated giant cells. This granulomatous formation contained clusters of numerous small veins. It is surmised that this Crassicauda infection did not play a significant role in the cause of death, since it was accompanied by only moderate pathological changes.

Since this worm was very long, the anterior and the posterior parts were not included in the tissue sampled for sectioning. 


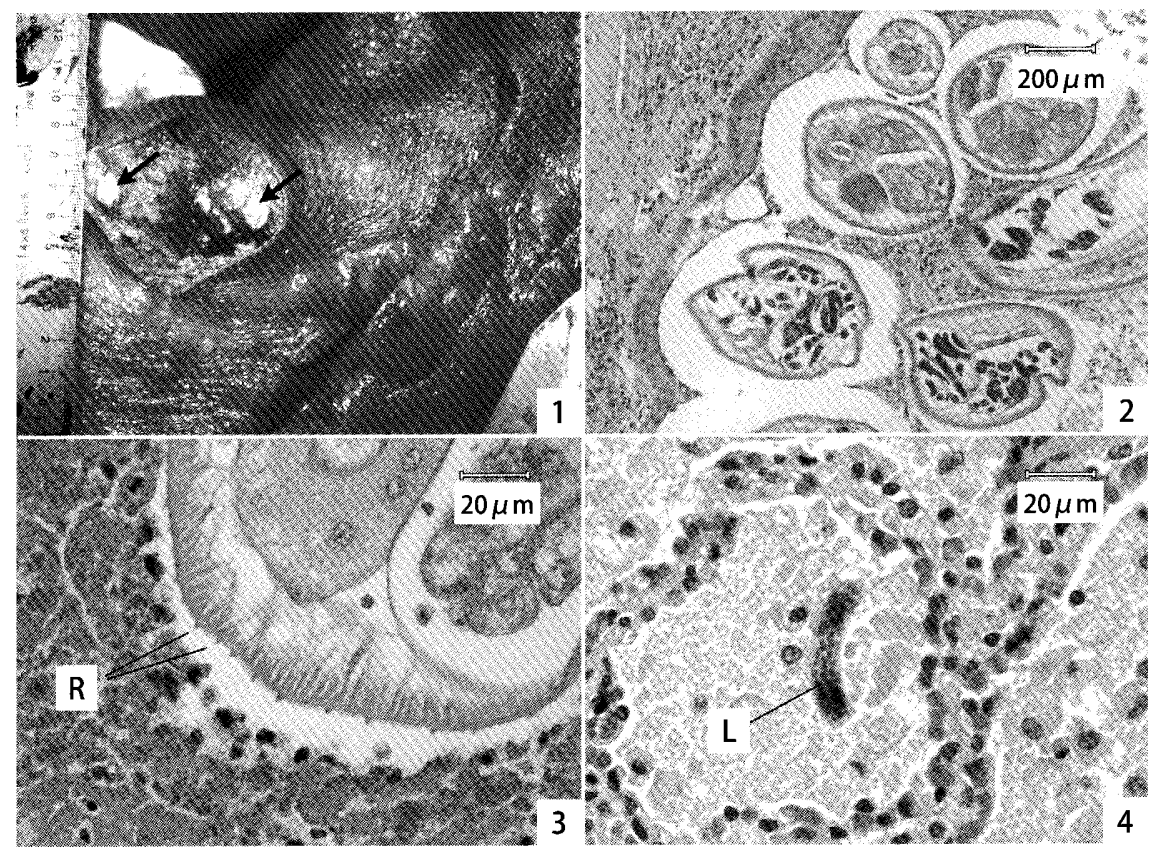

Fig. 1 Macroscopic view of the lung with abscesses (arrows).

Fig. 2 Bronchiole lumen containing a few adult worms as well as cell debris and exudates.

Fig. 3 A higher magnification of an adult worm showing ridges ( $R$ ) on its cuticle surface.

Fig. 4 Alveoli containing a large amount of amorphous material together with a larval worm (L).

By mincing the remaining tissue carefully, 2 fragments of the female, 7.0 and $5.0 \mathrm{~cm}$ long and $1.6 \mathrm{~mm}$ wide, were recovered. They were deposited in the National Science Museum, Tokyo, under accession number NSMT-As 3029. The body was yellowish, undulated with an irregularly wrinkled surface, and had uteri containing numerous eggs. The eggs were ellipsoidal, 42-46 (mean $44.1 \pm 1.0$ S.D.) $\mu \mathrm{m}$ by 27 - 30 (mean 28.4 \pm 0.8 S.D. $\mu \mathrm{m}(\mathrm{n}=50)$, and contained developed larvae. The eggshell thickness was $4 \mu \mathrm{m}$ at the equatorial portion and $3 \mu \mathrm{m}$ at the poles. These characteristics identified the worm as belonging to Crassicauda, the only Spirurida genus known from cetacean tissues [5].

The clinical aspects of the present case suggest an involvement of bacterial infection in development of the disease, which subsequently led to death. This is consistent with the notion that an associative participation of helminths and pyogenic microflora seemed to be involved in the development of the disease observed in bottle-nosed dolphins infected with $S$. ovatus $[6,7]$. In this respect, it should be noted that movements of the lungworms with their cuticular ridges (Fig. 3) would abrade the bronchiolar epithelium, causing metaplasia, which may have inhibited efficient mucus transport by cilia, consequently promoting bacterial proliferation.

The life cycles of the metastrongyloids of terrestrial mammals are heteroxenous, with either gastropods or oligochaetes as the intermediate host. However, the life cycles of those in marine mammals are poorly understood. Recent experimental studies demonstrated that larval development occurs in fish but not in marine invertebrates, suggesting that fish are the intermediate host [8]. Therefore, feeding thawed fish rather than raw fish to dolphins may be recommended to avoid Stenurus infections in aquaria.

We gratefully acknowledge the helpful suggestions and discussions of Dr. T. Moriki, Dr. T. Takahashi, and Dr. M. Toi, and the proofreading of the manuscript by Mr. D. Ribble, of the Kochi Medical School, Kochi.

\section{要 約}

和歌山県太地沖で捕獲され高知市の水族館で飼育されていた バンドウイルカ Tursiops truncatus が気管支肺炎で死亡し, 剖 検したところ肺虫 Stenurus ovatus (Linstow, 1910)（線虫綱： 変円虫上科：シューダルス科）の成虫が多数，細気管支内腔に 見られた。病態の進行には肺虫感染と細菌叢の相乗的な関与が 疑われた。

キーワード : 気管支肺炎, 線虫, バンドウイルカ

\section{REFERENCES}

1. Hasegawa H, Kumazawa H, Yona R, Hirai M. 2005. 
Redescription of Stenurus ovatus (Linstow, 1910) Baylis et Daubney, 1925 (Nematoda: Pseudaliidae) from the bottle-nosed dolphin Tursiops truncatus (Cetacea: Delphinidae). Biogeography 7: 1-6.

2. Reidarson TH. 2003. Cetacea (Whales, Dolphins, Porpoises). In: Zoo and Wild Animal Medicine, 5th edition (Fowler ME, Miller RE. eds). pp. 442-459. Saunders, St. Louis, U.S.A.

3. Turnbull BS, Cowan DF. 1999. Angiomatosis, a newly recognized disease in Atlantic Bottlenose Dolphins (Tursiops truncatus) from the Gulf of Mexico. Vet Pathol 36: 28 - 34.

4. Department of Veterinary Pathology, Osaka Prefecture University 2001. Dolphin's lung, specimen \#761 presented at the 40th Meeting on Veterinary Pathology. Nisseiken Dayori 47:12 (in Japanese).

5. Chabaud AG. 1975. No. 3. Keys to genera of the order Spirurida. Part 2. Spiruroidea, Habronematoidea and
Acuarioidea. In: $\mathrm{CIH}$ Keys to the Nematode Parasites of Vertebrates (Anderson, RC, Chabaud, AG. eds). Commonwealth Agricultural Bureau, Farnham Royal, Buckinghamshire, U.K., 58pp.

6. Krivokhizhin SV. 1997. The role of lung helminths in Black Sea dolphin mortality. Euro Res Cetaceans 10: 296-297.

7. Birkun A Jr. 2002. Natural mortality factors affecting cetaceans in the Black Sea. In: Cetaceans of the Mediterranean and Black Seas: State of Knowledge and Conservation Strategies (Notarbartolo di Sciara G. ed.). A report to the ACCOBAMS Secretariat, Monaco, February 2002, Section 16, 13pp.

8. Houde M, Measures LN, Huot J. 2003. Experimental transmission of Pharurus pallasi (Nematoda: Metastrongyloidea), a lung worm of the cranial sinuses of the beluga whale (Delphinapterus leucas), to fish. Can J Zool 81: 364-370. 